УДК 78.071.1

DOI:

Катерина Івахова, кандидат мистецтввознавства, доцент кафедри теорії $і$ методики музичного мистецтвва Хмельницької гуманітарно-педагогічної академії

\title{
КОМПОЗИТОРСЬКА ТВОРЧІСТЬ НАРОДНОГО АРТИСТА УКРАЇНИ МИКОЛИ БАЛЕМИ
}

У статті висвітлюються жанрово-стильові пріоритети авторської музичної творчості відомого украӥнського композитора, багатолітнього художнього керівника і головного диригента Хмельницького академічного ансамблю пісні і таниюю “Козаки Поділля” Миколи Балеми. Звертається увага на його численні начіонально-патріотичні, духовно-літургічні, фольклористичні, лірико-побутові артефакти, опери "Вічний етап” (Кармалюк) i “Пророк” (Т. Шевченко) тощо. Музика композитора характеризується широкою палітрою музичної творчості обумовленою зверненням майже до всіх музичних форм: опера, симфонія, кантата, ода, літургія, сюїта, балада, соната, романс, мюзикл, естрадні пісні (фольк, рок, джаз, поп), музика для театру, обробки украӥнських народних пісень. Загалом композитор створив майже 700 музичних різножанрових творів: 11 вокально-хореографічних композицій, сюїт, 13 вокально-симфонічних творів, 200 обробок історичних, козачьких, родинно-побутових, святково-календарних народних пісень Поділля та Украӥни, 26 творів для академічного хору на вірші украӥнських поетів та 31 дитячу пісню.

Ключові слова: Микола Балема; вокально-хорова музика; народна пісня; національні традииіі; музична мова; музичний образ; музичний модерн; "Козаки Поділля”.

Jim. 10.

Kateryna Ivakhova, Ph.D.(Art Studies), Associate Professor of the Theory and Methodology of Musical Art Department Khmelnytskiy Humanitarian Pedagogical Academy

\section{COMPOSER WORK OF FOLK ARTIST OF UKRAINE, MYKOLA BALEMA}

The genre-style priorities of vocal and instrumental creativity of the famous Ukrainian composer, long-time artistic director and chief conductor of the Khmelnytskiy Academic ensemble of song and dance "Cossacks of Podillya" Mykola Balema are elucidated. Attention is drawn to his numerous national-patriotic, spiritual-liturgical, folkloristic, lyrical-customs artifacts, operas "Eternal Stage" (Karmalyuk) and "Prophet" (T. Shevchenko), etc. The composer's music is characterized by a wide range of musical creativity due to the appeal to almost all musical forms: opera, symphony, cantata, ode, liturgy, suite, ballad, sonatas, romances, musicals, pop songs (folk, rock, jazz, pop), music for the theater, adaptation of Ukrainian folk songs. In total, the composer created more 700 musical works of different genres: 11 vocal and choreographic compositions, suite, 13 vocal and symphonic compositions, 200 adaptations of historical, Cossack, family-related, holiday-calendar folk songs of Podillya and Ukraine, 26 works for the academic choir on poems of Ukrainian poets and 31 children's songs. On the basis of his own vocalchoral music, the composer created a number of various theatrical concert programs for choir, orchestra and ballet of the ensemble "Cossacks of Podillya". He wrote the series "Marches of Ukrainian Victory" for military brass bands. In his musical language, modern musical instruments with a national tradition, historical and cultural origins are organically combined with a projection of the aesthetics of Ukrainian national-cultural revival.

Keywords: Mykola Balema; vocal choral music; national traditions; musical language; a musical image; musical modernism; artistic thinking; "Cossacks of Podillya".

П остановка проблеми. Видатний український композитор, диригент, народний артист України, генералхорунжий Українського козацтва, кавалер орденів “Знак Пошани” i “За заслуги” III і II ступеня Микола Балема - одна з найбільш потужних i неординарних особистостей в музичному мистецтві не тільки Хмельницької області, а й всієї України. Його новаторська музична творчість розвинулась від народного, загальноавангардного стилю до романтичного розуміння світу, глибокого сучасного філософського мислення. Чимала музична література композитора базується як на традиційних, так і на нових постмодерністських принципах оновлення образно-тематичного i жанрово-стилістичного художнього мислення, обробки народної пісні, поширенню різних жанрових типів сучасної пісні і музики, використання нових прийомів розкриття художнього образу, що має важливе теоретичне і практичне значення. Однак, самобутній, яскравий композиторський талант М. Балеми не знайшов належного висвітлення в науковій літературі.

Мета статті - висвітлити особливості авторської музичної творчості відомого українського композитора М. Балеми. 
Виклад основного матеріалу дослідження. Микола Панасович Балема народився 1 травня 1948 в с. Жилинці на Ярмолинеччині). Закінчивши Хмельницьке музичне училище і Свердловську консерваторію, М. Балема 31972 по 2018 рр. очолював ансамбль пісні і танцю "Подолянка", який за його ініціативою в 1992 р. перейменований в “Козаки Поділля" Хмельницької обласної філармонії [8].

Авторська музична творчість М. Балеми - це не тільки наслідування загальноєвропейських романтично-імпресіоністських традицій, а й помітне втілення новітніх парадигм естетики імпресіонізму, неофольклоризму, постмодернізму зі своєрідністю мелодичних ліній, їх інтонаційної та ритмічної будови, модерними звукосполученнями, дисонуюччими співзвуччями, вільною хроматикою. У композитора відбувається характерна для його творів видозміна традиційного в українській музиці терцовосекстового інтонаційного контуру за рахунок модернізації септимових, квартових, тритонових, секундових рухів, а також використання різноманітних кластерів, діатонічних, горизонтально-мелодичних, сонористичних фактурних комплексів. Тобто, митець наповнює традиції музичного мистецтва авангардною музичною мовою. При цьомув його музичній мові органічно поєднуються модерністські музичні засоби з національною традицію, історикокультурними витоками з проекцією на естетику українського національно-культурного відродження.

Варто наголосити, що вищевказані характерні (“емансиповані”) особливості розвитку широкої палітри музичної творчості М. Балеми обумовлені зверненням майже до всіх музичних форм: опера, симфонія, кантата, ода, літургія, сюїта, балада, соната, романс, мюзикл, естрадні пісні (фольк, рок, джаз, поп), музика для театру, обробки українських народних пісень. Загалом композитор створив майже 700 різножанрових музичних творів: 11 вокально-хореографічних композицій, сюїт, 13 вокально-симфонічних творів. Звернення М. Балеми до жанру оперно-симфонічної музики було зумовлене досконалим професіоналізмом і пошуками нової для себе музичної виразності. Композитором створено дві опери: "Вічний етап" (Кармалюк) на лібрето М. Балеми за поезією П. Гірника (1993) і “Пророк” (сумісно 3 Б. Балемою, лібрето М. Балеми за творами Т. Шевченка, 2014), симфонієту “Товтри” (1971), симфонічну поему "Поділля" (1972), рапсодії “Кохаймося, братове” (1982), “Зоряний шлях” з хором і солістами(1997)i“'Вітаємо Карпати!”(2002), симфонію України (2007), джаз-увертюру “Свято” (2012).
У широкомуспектрі індивідуально-оригінальних жанрово-стилістичних формотворень виділяються: симфонічна картина "Під мирним небом" для симфонічного оркестру, фортепіано і бандури з хором на власні вірші (1980), пісні-реквієми “Хлопці, що стали цвітом” (1999) для вокального дуету, хору і оркестру на вірші М. Воньо та "Прохання Небесної Сотні" (2014) для хору, оркестру і вокального квартету на вірші Р. Балеми, ода “Орися ж ти, моя ниво” (2006) для хору й оркестру на вірші Т. Шевченка, балада "Іменем любові” (2006) для хору й оркестру на вірші Р. Балеми, кантата “Благослови, Боже” (2008) для альта, тенора, хору і оркестру на вірші Б. Грищука, кант “Збудуймо наш Храм” (2010) для тенора й оркестру на вірші Р. Балеми, перший на Поділлі мюзикл “Сонячна соната" (2010) спільно 3 Б. Балемою за однойменним вінком сонетів Р. Балеми, кантата "Молюсь за тебе, Україно" (2012) для сопрано, тенора, хору і оркестру на вірші В. Мазура, сюїта “На вітрах Карпат” (2017) для хору, оркестру і соліста за поезією І. Куриліва.

Наслідуючи традиції М. Лисенка та М. Леонтовича, М. Балема написав 26 творів для академічного хору на вірші українських поетів та 31 дитячу пісню, в значній мірі втілюючи в них дух народного музично-пісенного фольклору [9]. Враховуючи необхідність інсценізації концертних номерів ансамблю пісні і танцю, композитор надавав репертуару театралізованого змісту. Однією $з$ перших таких композицій стала “В'язанка подільських жартівливих пісень”, в основу якої покладений вірш С. Руданського "У неділю на риночку”. Поєднуючи фольклор 3 сучасними засобами музичного мистецтва М. Балема створив багато власних творів, характерних для народно-пісенної фонеми. До них, зокрема, належать крупні вокально-хореографічні композиції: хорові сюїти "Вінок Поділля" та "Тосітосі”; вокально-хореографічна сюїта “Шевченкіана" ("I серцем лину”, "Розрита могила”, “Чигирине, Чигирине...”, “Мені однаково чи буду”, “Не питайте, чорнобриві”, “Защебече соловейко”, “Сонце заходить”, “Садок вишневий коло хати”); інструментально-хоровий концерт “Думкашумка”, “Божественна літургія Іоана Золотоустого" [4; 7]. Всеукраїніським козацьким гімном, символом українського національного відродження стала пісня М. Балеми на вірші М. Воньо і П. Карася "Козацькому роду нема переводу" $[1,4-5]$.

М. Балема зробив близько 200 обробок історичних, козацьких, родинно-побутових, святково-календарних народних пісень Поділля та України. Більшість 3 них видані в трьох томах 
циклу “3 народної криниці““ (2016, 2017, 2018). Численні його артефакти героїко-епічного плану охоплюють історичні пісні і думи (наприклад: “Дума про Хмеля”, “Гей, не дивуйте”, “Ой на горі женці жнуть”, “Максим козак Залізняк”, “Стоїть козак на чорній кручі”), яким притаманний гомофонно-гармонічний виклад із елементами речитетації, імітаційної та підголоскової поліфонії. Фактурні прийоми збагачуються вмілим використанням тембрової палітри хорових голосів, гармонічною колористикою, продуманою динамічною шкалою [5; 6].

Використовуючи нові виразові прийоми, прагнучи більш радикально оновити палітру хорового письма, М. Балема втілює новий, джазовий, принцип обробки народних пісень “Ой гай, гай”, “Ой під вишнею”, “Од Києва до Лубен”, “Чорноморець”, “Було літо, було літо”, “Ой у полі три криниченьки”, “Їхали козаки”, “Зеленеє жито, зелене”, “Ой підемо жінко”, “А мій милий вареничків хоче” та багато інших. Багато ліричних пісень композитора набули неабиякої популярності, як, скажімо: “Ой там на вигоні”, “Твоє весілля”, “Здраствуй, рідне село”, “Пишногорда”, “Батько” на вірші М. Воньо та інші [6]. Виразність мелодії, відповідність тематики та змісту, простота викладу характерні для 30 пісень, написаних для дітей і молоді як посібник для вчителів музики під назвою "Ми будуємо Україну” (“Ми вірні друзі”, “Танець дружби”, “Канікули”, “Останній дзвінок”, “Випускний вальс”, “Волонтери”), про любов до України, наших звичаїв, історії, погляд у майбутнє (“Отчі причали”, “Найкраща мені Україна”, “Ми будуєм Україну”, “Я уславлю мою Україну”, "Україна наш сад”, “Бережи, мій Боже, Україну" тощо) [3].

На основі власної музики композитор створив низку різнотематичних театралізованих фольклорно-етнографічних концертних програм для хору, оркестру і балету ансамблю "Козаки Поділля”, зокрема: "Красо України, Подолля”, “Україна, любов, майбуття...”, “Ми єсть народ!”, “Україно, матінко моя”, “На лезі шаблі наша воля!", “Подільські вечорниці”, “Весна на Поділлі”, “Поділля щедрує”, “Ой на Івана та на Купайла”, “Ваша величносте, жінко!”, “Козацька рада” та багатоінших. Вних він використовує фольклористичні елементи сучасної музичної виразовості як в гармонії, так і в фактурі [10, 117 - 121].

Композитор М. Балема написав цикл "Марші української звитяги” для військових духових оркестрів, що стало важливим творчим внеском в українську музично-пісенну культуру. Історія духових оркестрів нерозривно пов’язана з історією армії і флоту, із суспільно-політичним життям країни і духовно-культурними процесами на містах і села, трудових колективах на Хмельниччині до недавнього часу духові оркестри мали досить значне поширення, що засвідчувало поважливе до них ставлення влади і населення. Духові оркестри були невід'ємним атрибутом громадських i культурно-побутових заходів, проводились концерти, свята духової музики і марш-паради духових оркестрів. Збірка партитур М. Балеми “Марші української звитяги” стала новим кроком щодо збереження традицій духової музики i поповнення так необхідного і дефіцитного репертуару духових оркестрів. Новизна і свіжість створених композитором артефактів полягає в їхньому суто індивідуальному українському форматі. Зокрема, козаччина, як звитяжна історія і велика гордість нашого народу, душа України, іiі надія і оберіг, знайшла відтворення в творчості М. Балеми. Композитор зробив цікавий оркестровий переклад низки мелодій власних знакових козацьких, патріотичних пісень (“Козацькому роду нема переводу”, “Ми - твої, Вкраїно, козаки”, “На лезі шаблі наша воля!”, “За Київську Русь”, “Повстанський марш”, “Слава ветеранів”, “Перемога”, “Слава синам України”, “Вставай Україно”, “Будьмо гонорові”, “Рушник єднання”, “Марш прикордонників”, “Прикордонні війська"), а також оригінальні інструментовки популярних українських народних пісень (“Ой на горі там женці жнуть”, “Їхали козаки”, “Маруся”). Характерною особливістю цих партитур є їх своєрідна суто українська національнопатріотична пісенна змістовність 3 яскравіше виявленою динамікою руху в порівняні з простими маршами масового характеру. У загальному характері цих маршів виділяється взаємодія оригінального “моторного” (метро-ритмічного) інструментального тла і широка своєрідна розлога поліфонічна наспівність “внутрішніх" (баритонових) і підголоскових мелодичних ліній та можливості ефективного супроводу вокальнохорового виконання пісень [2].

Окреслюючи жанрово-стильові пріоритети Майстра як віддзеркалення його психоемоційного “словника", приходимо до висновку, що попри розмаїття жанрів центральне положення займають вокально-хорові композиції. Високий художньо-естетичний рівень змістовності його вокально-хорової музики забезпечувався зверненням до кращих зразків української класичної та сучасної поезії - Т. Шевченка, Л. Українки, В. Сосюри, Л. Костенко, Б. Олійника, Д. Павличка, П. Гірника, М. Луківа, Б. Грищука, П. Карася, Р. Балеми, М. Воньо, М. Войнаренка, В. Міхалевського, М. Дорожка та до власної 
поезії. Сама специфіка пісенних жанрів 3 їі інтимним тоном висловлювання, самозаглибленням і тонкою психологічною градацією найкраще відповідали витонченій натурі музикантапатріота. Оцінюючи соціально-психологічну роль композиторської творчості М. Балема зауважує: “...Але ж не в тому суть, що це моя пісня чи обробка, а в тому, що в результаті моєї композиторської роботи над подільським фольклором народжується твір, наскрізь пронизаний національним духом. Нині треба перепробувати всі засоби, використовувати найменші можливості, щоб повернути людям пам'ять, відкрити їм очі на втрачене багатство" $[1,3]$. Разом 3 очолюваним колективом "Козаки Поділля" М. Балема представляв культуру області та України в Росії, Латвії, Молдові, Франції, Іспанії, Греції, Болгарії, Бельгії, Нідерландах, Англії, Індії, Швейцарії, Польщі та інших державах [10].

Висновки. Власне педантизм і скрупульозність М. Балеми, схильність до глибокого аналізу явищ, різнобічність інтересів стали соціальнопсихологічними підвалинами його полістилістичної творчої орієнтації, вельми індивідуального трактування того чи іншого музичного стилю. Композитору імпонують високі ідеали національної духовності, інтерес до світу людської душі, символічність образів. 3 іншого боку багатосторонній синтез жанрів і стильових “знаків” засвідчує інтелектуальну спрямованість його оригінальних композицій.

\section{ЛІТЕРАТУРА}

1. Балема М. Козацькому роду нема переводу. Збірник пісень. Городок, 1991. 268 с.

2. Балема М. П. Марші української звитяги: партитури для військових духових оркестрів. Хмельницький: Заколодний М. І., 2015. 169 с.

3. Балема М. П. Ми будуємо Україну. Пісні для дітей та молоді : посібник для вчителів музики. Кам'янець-Подільський : ПП Буйницький О. А., 2008. $140 \mathrm{c}$.

4. Балема М. П. Божественна літургія Іоана Золотоустого. До 1025-ліття хрещення РусиУкраїни. Хмельницький, 2013. 137 с.

5. Балема Микола Панасович. 3 народної криниці : обробки українських народних пісень для хору та оркестру. Т. 1. Хмельницький, 2016. 180 с.

6. Балема Микола Панасович. 3 народної криниці : обробки українських народних пісень для хору та оркестру. Т. 2. Хмельницький, 2017. 189 с.

7. Вокально-хорова Шевченкіана композиторів Хмельниччини. Упор. Д. Тукало. Хмельницький, 2006. $56 \mathrm{c}$.

8. Івахова Катерина. Композитори Хмельниччини (авторська та музично-педагогічна діяльність). Молодь і ринок. №7 (126). 2015. С. 45-51.

9. Кропивницький В. Музично-пісенна творчість митців Поділля. Хмельницький, 1999. $285 \mathrm{c}$.

10. Римар Росіна. Ансамбль пісні і танцю “Козаки Поділля" у світлі національних традицій. Молодь і ринок. 2006. №5. С. 117-121.

\section{REFERENCES}

1. Balema, M. (1991). Kozatskomu rodu nema perevodu. Zbirnyk pisen [There is no translation for the Cossack family. Collection of songs]. Horodok, 268 p. [in Ukrainian].

2. Balema, M. (2015). Marshi ukrainskoi zvytiahy [Marches of Ukrainian victory]. Khmelnytsky, 169 p. [in Ukrainian].

3. Balema, M. (2008). My buduiemo Ukrainu (pisni dlia ditei ta molodi) [We are building Ukraine. Songs for children and youth]. KamyanetsPodilsky,140 p. [in Ukrainian].

4. Balema, M. (2013). Bozhestvenna liturhiia Ioana Zolotoustoho. Do 1025-littia khreshchennia Rusy-Ukrainy [Divine Liturgy by John of Gold. By the 1025th anniversary of the baptism of Rus-Ukraine]. Khmelnytsky, 137 p. [in Ukrainian].

5. Balema Mykola (2016). Z narodnoi krynytsi [From People's Well]. Vol.1. Khmelnytsky,180 p. [in Ukrainian].

6. Balema Mykola (2017). Z narodnoi krynytsi [From People's Well]. Vol.2. Khmelnytsky, 189 p. [in Ukrainian].

7. Vokalno-khorova Shevchenkiana kompozytoriv Khmelnychchyny (2006). [Vocal-choral Shevchenko film composers of Khmelnytsky]. (Ed.). D. Tukalo. Khmelnytskyy, 56 p. [in Ukrainian].

8. Ivakhova Kateryna (2015). Kompozytory Khmelnychchyny (avtorska ta muzychnopedahohichna diialnist) [Composers of Khmelnitsky (author's and musical-pedagogical activity)]. Youth \& market. No.7 (126), pp. 45-51. [in Ukrainian].

9. Kropyvnytskyi, V. (1999). Muzychno-pisenna tvorchist myttsiv Podillia [Musical and song creativity of artists of Podillya]. Khmelnytskyi, 285 p. [in Ukrainian].

10. Rymar Rosina (2006). Ansambl pisni i tantsiu "Kozaky Podillia" u svitli natsionalnykh tradytsii [Ensemble of song and dance "Cossacks of Podillya" in the light of national traditions]. Youth \& market. No.5. pp. 117-121. [in Ukrainian].

Стаття надійшла до редакції 10.05.2019 